\title{
Gated Communities in England: rules and rhetoric of urban planning
}

\section{Sarah Blandy, David Parsons, Sheffield}

\section{Introduction}

A new form of housing has been introduced into England: the walled or fenced housing development to which public access is restricted, often guarded using close-circuit television (CCTV) and/or security personnel. These gated communities are governed by legal agreements which tie the residents to a common code of conduct and to collective responsibility for managing the development. This article concentrates on private gated communities in urban settings. It must be noted that there are some social rented housing estates in England which have been gated as a deterrent to crime, and in an attempt to develop a sense of neighbourhood; this type of gated community is outside the focus and scope of this article.

Advertisements for houses and apartments in privately owned gated communities are now numerous in the property supplements of any national newspaper. The number of gated communities is growing in urban areas:

«There are no estimates of absolute numbers in England or London but it is difficult to walk very far in many sections of the city without encountering walled estates already standing or in construction» (Gooblar 2002: 322).

These developments are changing our cityscapes. In form and appearance they are far removed from the traditional English ideal dwelling or development type.

Many British developers are interested in building this type of housing, not surprisingly given the phenomenal spread of gated communities in the States (see WebsTER 2001). Consumer demand for housing in gated schemes may, at least partly, be affected by the well-documented loss of networks of trust and mutual reliance in current Western society (see for example, Putnam 2000; Garland 2001). Accompanying these changes is what GARLAND describes as the «crime complex», a process which makes high crime rates into a fact of life, dominating the media and public policy (GARLAND 2001:163). At the same time, the globalised media is feeding housing consumers with images of an aspirant lifestyle featuring modern design, security, and access to private leisure facilities (see THORNs 2001).
In 2002 a telephone survey on attitudes to gated communities, of a random sample of 1001 respondents throughout the UK stratified for region, gender, age and income, was carried out on behalf of the Royal Institute of Chartered Surveyors (Live StRATEgy 2002). Those in favour of gated communities were more likely to be younger respondents: $65 \%$ of $18-24$ years old compared to $44 \%$ of those aged $65+$. Notably, renters were more in favour than were home owners, and this positive view also correlated with low income. Thus the demand for gated communities may, at least partly, be driven by a need for security, as research has shown that neighbourhood dissatisfaction and fear of crime disproportionately affect people on low incomes and living in rented housing (Burrows \& RHODEs 2001; Home OfFICE 2002).

Clearly, both supply and demand have played their parts in the increasing popularity of private gated communities in this country, although they are not (yet) as widespread as in the US. In this article we use a case study to examine the reasons why residents may be attracted to live in a gated community in England. Drawing on this case study and on previous research into English gated communities (CASTELl 1997; GooBLAR 2002), we investigate the extent to which local planning decisions about the development of such schemes conform to national urban policy. First, we consider how trends in the style of housing are transforming the look of England's urban residential areas.

\section{Globalisation of the housing market}

The «ideal» dwelling in England is traditionally represented by a detached house with a garden, owned on freehold tenure, and situated in a village or leafy suburb. It is a place of security and seclusion, conforming with the old adage «an Englishman's home is his castle». However, many features of gated communities seem at odds with these assumptions. They include a large proportion of apartments; other dwellings are described as «townhouses», but are actually tall, narrow, vertical slices of an old building, joined on both sides to their neighbours. Residents in gated communities cannot withdraw into their own property and ignore their neighbours, partly because of their physical closeness, and partly because of the legal framework which requires collective management of the development. Globalisation provides a possible explanation for the consumer choice of a gated community 
in preference to the traditional English house and garden.

Globalisation has produced what BECK describes as: «a single commodity-world where local cultures and identities are uprooted and replaced with symbols from the publicity and image departments of multinational corporations» (BECK 2000: 43, emphasis in the original).

Robinson (2002: 23) suggests the reasons for this phenomenon are part of an:

«holistic corporate strategy of shaping lifestyle, in as many of its dimensions, and for the greatest proportion of its total duration, as possible»,

with the aim of shaping the consumer to desire what the market has to offer.

The «urban aesthetic» dates back to 1980's New York when loft living became fashionable there. Apartments and townhouses created from existing, historic buildings are very compatible with the new urbanist trend in architecture. Some commentators have suggested this trend indicates a desire to return to a mythical time of neighbourliness and community, to create a sense of belonging (see Morley 2001). As a Chicagobased designer put it:

«The children of the sexual revolution are looking to put romance back in their lives and return to traditional lifestyles. (...) People seem to be looking for touches they would have remembered from visiting their grandparents» (quoted in GARBER 2000: 20).

Access to the internet allows consumers to «log onto real estate sites and take a virtual tour through the properties not only in your own hometown but increasingly around the world» (THORNs 2001:4). Ideas about taste, not just in interior design but also in aspirational housing types, are thus spread around the world. In terms of design, we are inundated with magazines (Ideal Home, Elle Décor, Better Homes and Gardens, etc.) and television programmes (Changing Rooms, Other People's Houses, etc.) which influence how we want to live. Identical images are used worldwide in publicity material for trendy housing developments. The key themes here are luxury, leisure, sex (represented by idealised models of desirable young people), and security.

Publicity materials often specifically use the term «luxury». «Stylish show home décor and smart fixtures and fittings offer the prospect of an obtainable dream, a touch of designer chic and celebrity living» (HALIFAX New Homes Marketing Board 2001: 11). Security is another essential of modern life: property brochures frequently include details of CCTV, 24 hour guard systems, walls and electronic gates. This is despite the fact that crime figures in the UK have been falling for the past ten years, as reported in successive British Crime
Surveys (Home Office 2002). The images used and the security features described mean that:

«Potential buyers are sold, in short, the sense of community promised by a homogenous neighbourhood, responsibly managed, and protected from outsiders» (RoBINson 2002:5).

Leisure is often another selling point for gated communities: exclusive access to swimming pools and fitness suites. Finally, hi-tech features both within the dwellings as well as for the security devices are a common theme in advertisements.

The effect of this globalised approach is to change consumer attitudes. In England the traditional preference has been for older, detached properties, and for houses rather than flats. An extensive survey was carried out in 2000 to capture the views about new homes, of people in the home buying market (Halifax New Homes Marketing Board 2001). 36\% of respondents said they would consider buying a new property; six years previously it had been $25 \%$. Respondents identified a number of attractive features in newly built properties, primarily stylish design and convenience, in line with the globalised trend for low-maintenance, hitech homes. In the Halifax survey, potential buyers associated homes converted from existing buildings, with elegance and individuality, combining modern convenience and style with the traditional preference for older properties (Halifax New Homes Marketing BOARD 2001).

Gated communities conform to many of the preferences of globalised, rather than specifically English, taste and aspirations in housing. In the English housing market, urban apartments have become very popular, despite their inevitably higher density occupation. The next section examines whether such developments also conform to current urban policy.

\section{Urban policy in England}

The website of the Office of the Deputy Prime Minister (the government department responsible for local government, the regions, housing, planning and regeneration, which has replaced the Department of the Environment, Transport and the Regions (DETR) and the Department of Transport, Local Government and the Regions (DTLR)) displays this phrase: «Thriving, inclusive and sustainable communities in all regions» (http://www.odpm.gov.uk/). The concept of mixed or inclusive communities has been taken up by many influential policy-makers since it was first promoted as a way of avoiding the creation of problem areas (PAGE 1993). It is now a dominant feature of current government policy documents. For example, the Hous- 
ing Green Paper (Department of the Environment, Transport and the Regions/Department of Social SECURITY 2000) encourages mixed communities as a way of sustaining housing areas. Mixed tenure is generally seen as the means of achieving social balance in regeneration practice (see, for example, DePARTMENT of the Environment, Transport and the Regions 2000b).

Another key feature of current urban policy is the need to revitalise city centres (URBAN TASK Force 1999). The Urban White Paper (Department of the Environment, Transport and the Regions 2000a) combines these two issues, noting with approval the emerging evidence of re-population of the urban core, and stressing the importance of «inclusive communities». Britain is currently facing an unprecedented demand for housing in some areas. The preferred way to meet this need is through development of high density housing on brownfield sites, seen as a better alternative both to building on greenfield sites and to suburban sprawl. Many brownfield sites are in inner city neighbourhoods. The Urban Task Force recommended to the government that these

«New urban developments (...) should seek diversity; encouraging a mix of activities, services, incomes and tenures within neighbourhoods» (URban TASK Force 1999).

Given that urban policy currently supports inclusive communities, social balance and mixed tenure neighbourhoods, with a particular focus on the renaissance of city centre living, what is the role of the local planning process in putting this into practice?

\section{The planning framework}

The purpose of English planning legislation (primarily, the Town and Country Planning Act 1990) is to regulate the development and use of land in the public interest. Local planning authorities must draw up Development Plans for their area, «having regard» to any regional and strategic planning guidance and to current national policies, including Planning Policy Guidance Notes issued by the government. Local Development Plans are based on extensive consultation, but are not particularly detailed and can be overridden. Applications for planning permission should be decided by a local authority in accordance with its Plan, unless «material considerations» indicate otherwise. Local planning authorities have a large amount of discretion in dealing with individual planning applications.

The relevant Planning Policy Guidance Note 3: Housing (known as PPG3) places emphasis on the good design of high density developments on brownfield sites. In line with current urban policy, paragraph 10 of PPG3 states that:

«The government believes that it is important to help create mixed and inclusive communities, which offer a choice of housing and lifestyle. (...) Local planning authorities should encourage the development of mixed and balanced communities» (Department of the Environment, Transport and the Regions 2000c).

The companion guide to PPG3, Better Places to Live by Design (Department of Transport, Local GovERNMENT AND THE Regions (DTLR) 2001), is primarily concerned with design, but echoes the emphasis on mixed tenure and social balance:

«Mixed neighbourhoods of people of different ages and economic status and with different lifestyles (...) can provide a number of important community benefits. (...) Much recent housing has provided a limited range of tenure choices, often focusing on a narrow market segment or particular housing need.»

One way in which local authorities can ensure mixed tenure developments is by entering into agreements with private developers under section 106 of the Town and Country Planning Act 1990. Such agreements can require private developers to contribute to meeting the need for affordable housing by including either social rented housing or low cost homes for sale in their scheme. However, local authorities are able to «commute» the developer's obligation - releasing them from providing actual housing in the development under planning consideration, through payment of a sum which will enable affordable housing to be built elsewhere, or will enable social and other facilities to be provided for the neighbourhood.

When a planning application is received, the planning department of the local authority must consult with interested individuals (such as neighbouring residents) and organisations. The local highways authority will be consulted on all aspects of the access and internal roads of a new housing development. Design Bulletin 32 , issued by the government under the Highways Act 1980, states that roads which serve a development comprising five or more dwellings should be adopted by the local authority - meaning that the road is publicly accessible, built to adequate standards, and will be maintained by the local authority. However, Design Bulletin 32 is guidance only, and has no legal force. If a prior right of way existed through the site, the local authority could insist that public access to the new development is retained. If not, there appears to be insufficient power for the local authority to insist on internal roads being adopted.

Another source of guidance for local authorities is a government-approved police scheme to design secu- 


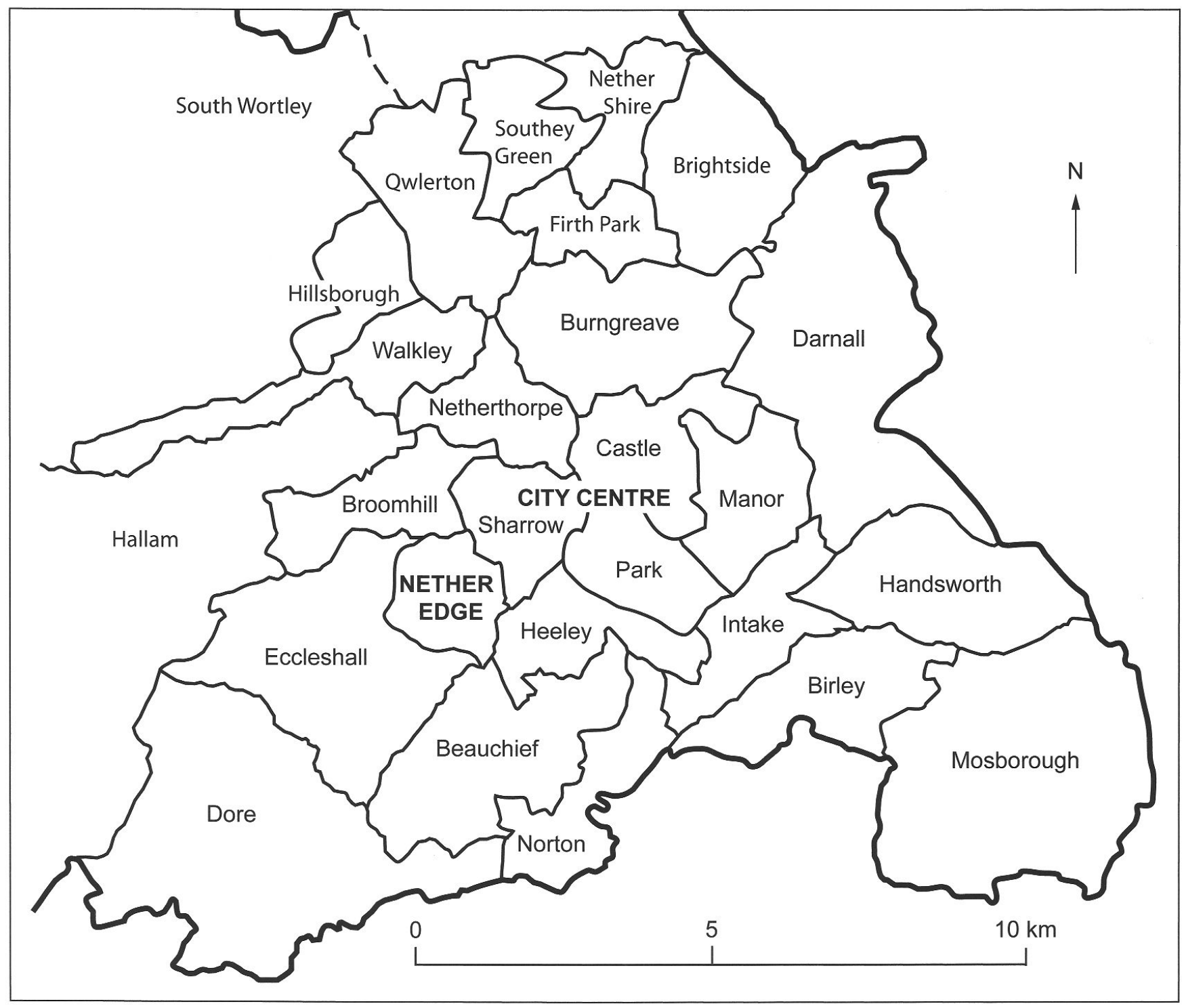

Fig 1: The boundaries of Sheffield local government wards

Les circonscriptions électorales locales à Sheffield

Die lokalen Wahlbezirke in Sheffield

Cartography: L. BAUMANN

rity into new homes, known as «Secured by Design» (ACPO Crime Prevention Initiatives Ltd 2003). This appears to support gated developments, rather than the principles of PPG3 and Design Bulletin 32. Secured by Design recommends «creating real or symbolic barriers for an estate» and «restricting access for the public through the estate to as few routes as possible». Thus local planning authorities are faced with a difficult combination: they must exercise discretion in applying their Development Plan to individual applications for planning consent; their powers under the Highways Act are weak; and they must take into account government guidance which gives conflicting advice on ensuring mixed communities and designing out crime.

\section{The case study}

The empirical data on which this article is based comes from a small-scale study, funded by the British Academy, of a gated community in Sheffield, a northern post-industrial English city with around half a million inhabitants. The gated community is located in Nether Edge, an affluent area not far from the city centre with tree-lined roads and distinguished Victorian architecture. Figure 1 shows the boundaries of local government wards within Sheffield. Nether Edge is in the prosperous southwestern sector of the city. The east and north are relatively deprived with high scores on the multiple deprivation index. Nether Edge is on the frontier between the two; the adjoining district of 


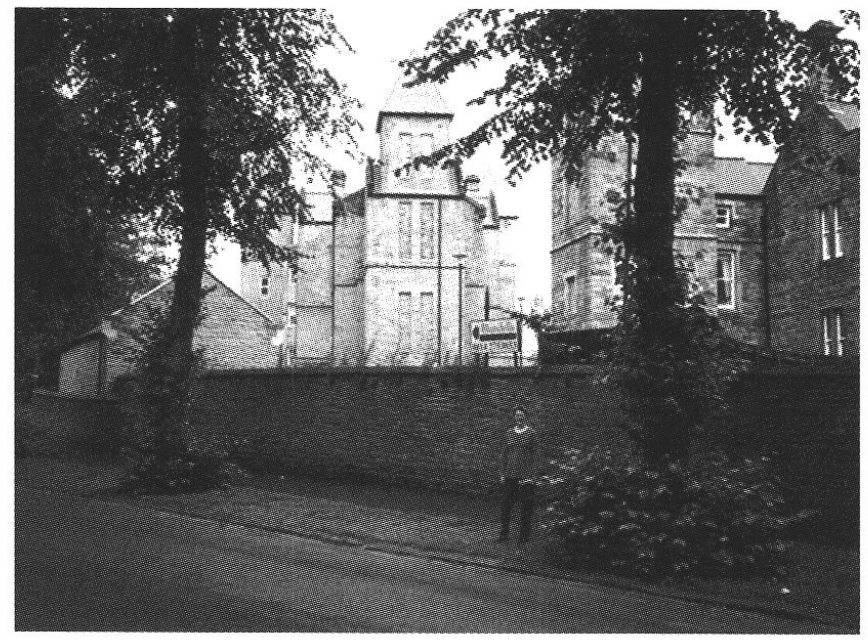

Photo 1: The original workhouse buildings and the surrounding stone wall

Les bâtiments originaux d'indigents, entourés d'un mur de pierre

Die originalen Gebäude des Armenhauses, umgeben von einer Steinmauer

Photo: J. Dixon

Sharrow is far less wealthy and is one of the most racially mixed areas of Sheffield.

The gated development, also confusingly named Nether Edge, was the first of its kind in the city. It was built on a site of 4.22 hectares (10.43 acres) which contained old hospital buildings. Some of these were originally built as a workhouse in 1841 to provide basic accommodation and subsistence for the destitute poor, in exchange for their labour. These buildings and the surrounding stone wall (see photo 1 ) were listed as Grade 2 architectural and historical importance, thus requiring Listed Building Consent before any alteration or demolition. When the Health Trust decided to sell the whole Nether Edge Hospital site, a detailed Planning Brief was drawn up by the local authority to ensure that the listed buildings were sensitively converted to new use (Sheffield City Council 1997).

Gleesons, a large national development company, invested $£ 30$ million in the purchase and conversion of the site to an exclusive residential development. The surrounding wall has been retained, and has now become the distinguishing feature of the development, as shown in photo 1 . The existing listed buildings have been converted to apartments and town houses, and new properties comprising both houses and apartments are being built (see photo 2), to make 180 dwellings in all. The development is high density occupancy, with some nicely laid out communal garden areas in the centre. It also includes leisure facilities and a swim- ming pool which are open only to residents. There are three access roads, all of which have electronically controlled gates. Figure 2 shows the site layout, with arrows indicating the access roads and gates. There are extensive CCTV cameras installed around the development, set up so that, for example, if anyone enters through a pedestrian access gate their movements through the site will be automatically tracked by a camera. Once the development of the site has been completed a security guard will be on duty during working hours, and overnight a control centre will take over responsibility for security.

Our study investigated the process of obtaining planning permission for this development. Interviews were carried out with two officers in the local planning authority (P1, responsible for Heritage and Design; and P2, responsible for development control), two highways department officers ( $\mathrm{H} 1$ and $\mathrm{H} 2$, respectively a chief engineer and a development control officer), and with the developer. Questionnaires were also distributed to all residents who moved in between June 2000 and November 2001, by which time 57 dwellings had been completed. 23 questionnaires were returned, and of these households 8 agreed to be interviewed.

\section{Nether Edge and the local planning process}

The Planning Brief (Sheffield City Council 1997) qualifies as Supplementary Planning Guidance, and was thus a material consideration in deciding planning applications for the site. The Brief included the request of the Director of Housing that approximately $20 \%$ of the housing on site should be affordable for people on low incomes, preferably in the form of social rented housing rather than low-cost housing for sale. However, most of the Planning Brief is concerned with the aesthetic and architectural considerations arising from the site. The local authority was looking for

«a comprehensive scheme that takes full advantage of the site's existing features and buildings, together with new build opportunities to create an interesting, visually stimulating and attractive mixed use environment, which has its own unique character and sense of place, fully respects the presence of important listed buildings and maintains a sense of historic association and continuity which is important to the local community» (Sheffield City CouncIl 1997: para. 4.2.1).

The public was consulted on the Planning Brief. A wide range of comments were received from individuals and local organizations concerning traffic issues, the appearance and conservation of the site, the provision of benefits for the wider community, social mix and community consultation. Planning permission was granted for Gleesons' housing scheme on $10^{\text {th }}$ January 


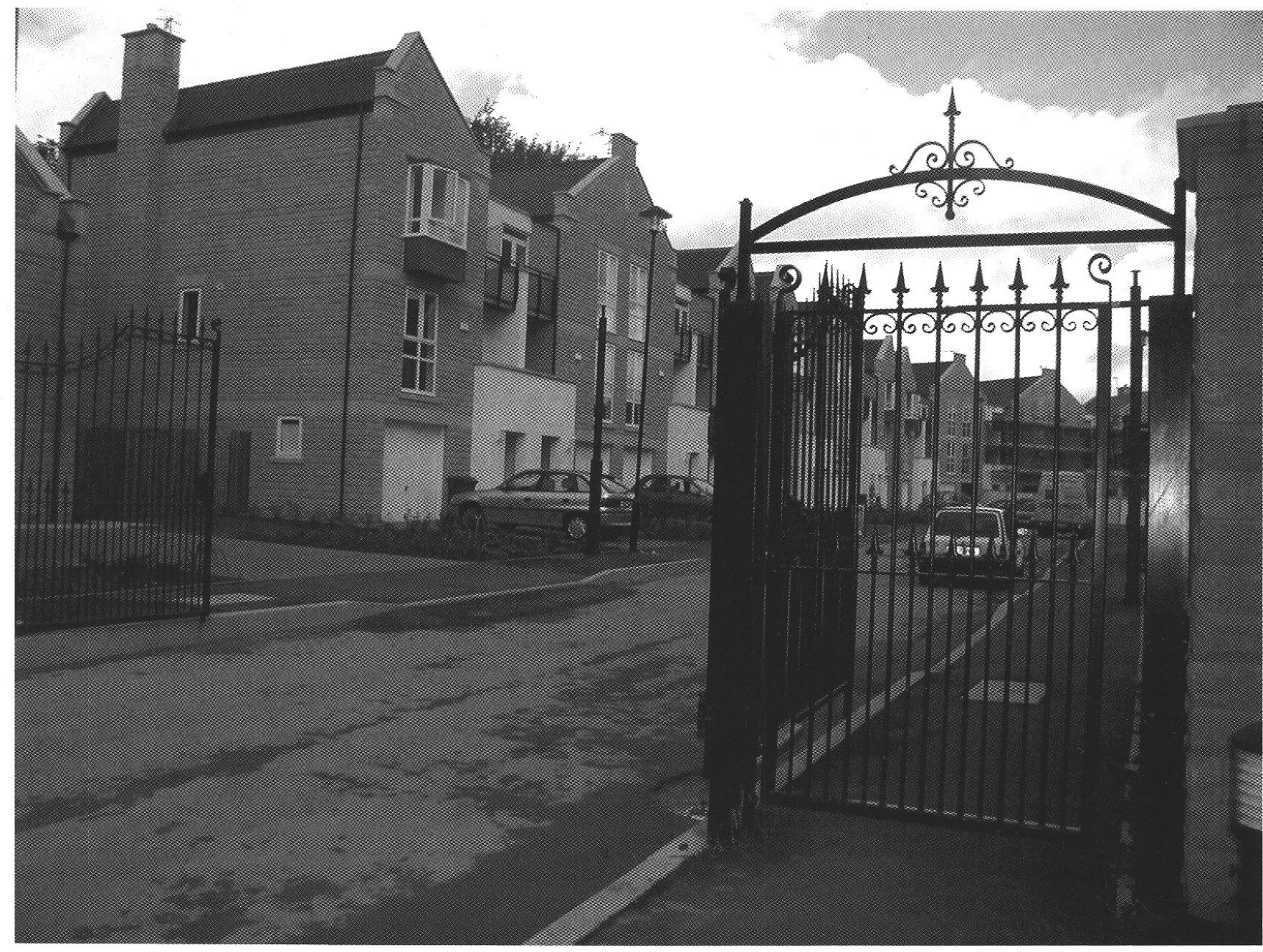

Photo 2: Newly built houses, and access gate

Des immeubles nouveaux et une barrière d'entrée

Photo: J. DiXon

Neue Gebäude und eine Einfahrt mit Zugangsbeschränkung

2000. Only seven responses to their application were received from local residents, and these were primarily concerned with details: two about the traffic impact on local roads, and one about the lack of social housing in the scheme. At the time, the planning application did not make it clear that the development was to be designed and managed as a gated community. This, along with the prior consultation on the Planning Brief, may account for the apparently low level of opposition or response to the planning application.

The interviews with the planning officers showed that the aim of social balance, identified above as a key feature in government urban policy, and included in the council's Planning Brief, was not taken into account at all in the planning process. Both interviewees $\mathrm{P} 1$ and $\mathrm{P} 2$ pointed out that the houses were so highly priced that the normal operation of the housing market was sufficient to ensure that the housing would be occupied by one class of resident. On the other hand the planning department did have the power to impose a degree of mixed tenure. Instead, it entered into a section 106 agreement and accepted a commuted sum from the developers.

Any planning control over the social mix or otherwise of the scheme would need to be based on an approved policy in the Development Plan for the City. There is no such policy in the current Plan, and the Issues Document on which the new Plan will be based does not include anything along these lines (SHEFFIELD CiTY CouncIL 2001). As interviewee P1 pointed out:

«But there is no explicit policy at present on gated communities. The main concern would be privatisation of public space. (...) All planning applications go to Development Control, and planning application response is more design-led than social-implication led.» 


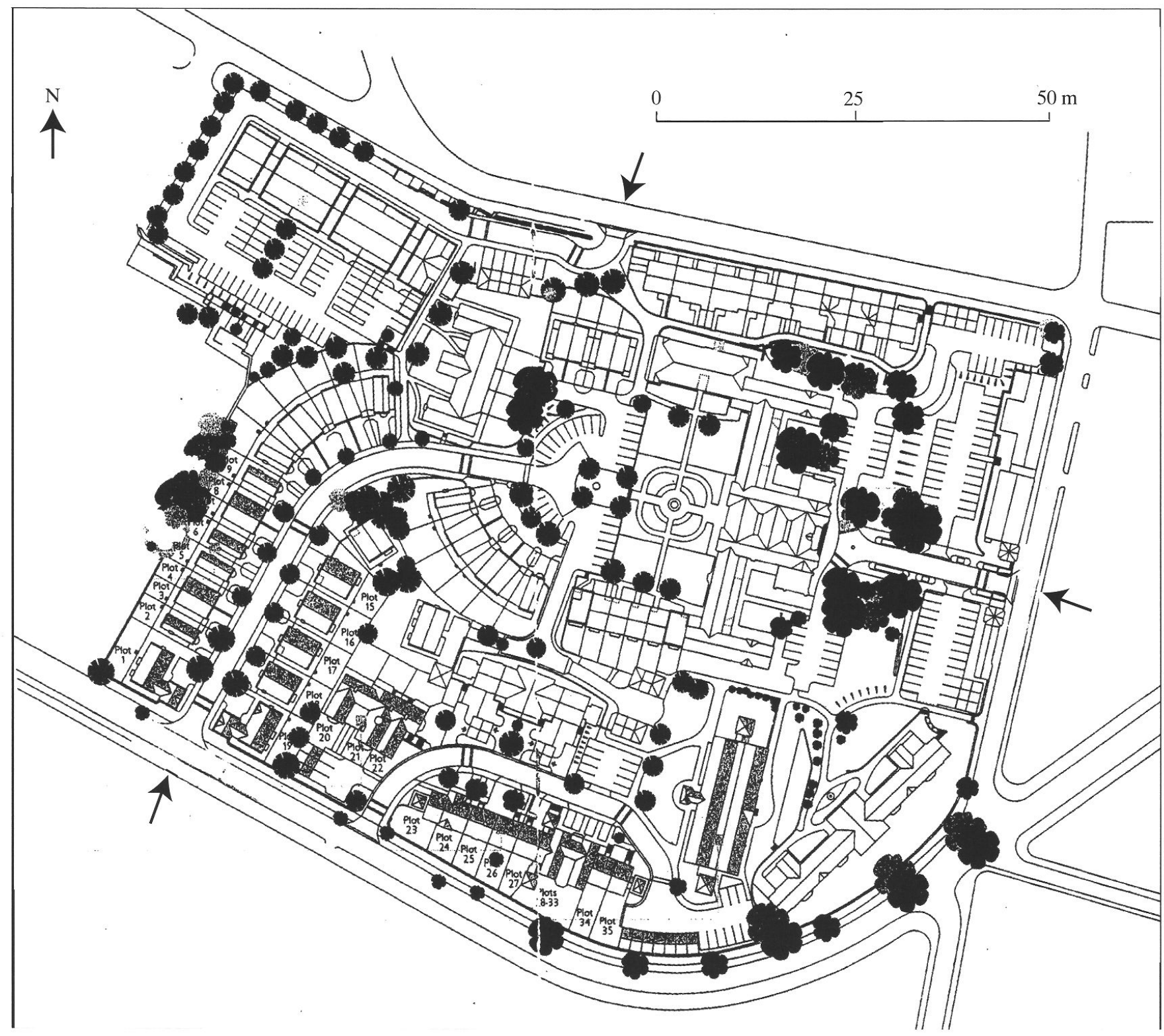

Fig. 2: Site layout for the gated community; the arrows indicating gated access roads.

Le plan du quartier fermé; les flèches montrent les entrées barrées.

Karte der geschlossenen Siedlung; die Pfeile zeigen die Einfahrten mit Zugangsbeschränkungen.

Both planners were well aware of the guidance contained in PPG3. Interviewee P1 said that «PPG3 is very explicit about encouraging high density schemes, etc., but it contains no tools to consider social exclusion». Interviewee P2 felt that «the scheme broadly conforms to the policy outlined in PPG3. It is a brownfield site and the density is high». He also felt that the developer would successfully challenge any decision based on social grounds:

«the developer would have appealed and the department would have had insufficient grounds to defend its decision at Public Inquiry».
The Highways Department did not anticipate that Gleesons would resist local authority adoption of the site's internal roads. Interviewee H1 explained that «traditionally, developers have wanted roads adopted so there are no maintenance charges to the residents». After planning permission had been granted, the developer and architects said they wanted the access and internal roads to be private, rather than public highways. The department could not legally insist on adoption of the roads in the Nether Edge site: «There was no point in letting it go to the magistrates court» $(\mathrm{H} 1)$. This was despite a policy in the Development Plan to 
adopt roads serving more than six houses. So, although the highways officers were concerned about the development setting a precedent,

«It was decided we might as well co-operate with the developers and see how it turns out. All we could do was insist on the standard of the road, and ensure that it doesn't become public» (H1).

Once the decision was made that the internal roads would not be adopted, «the highway authority wanted gates on, so that it was clear to the public that they are private roads» $(\mathrm{H} 2)$. The planning department was concerned for the management of the wider area: «gates were seen as a way of handling parking - to differentiate the site from the wider area and to keep other local residents from parking on the site» (P1). Other physical aspects were also taken into account:

«The main question about gates is whether they are physically safe and whether they intrude onto public space rather than any issue of whether the estate itself is part of the public realm» $(\mathrm{P} 2)$.

It was also pointed out by these officers that gates and walls are in accordance with the guidelines in «Secured by Design». Thus the gates themselves were not a problem; the only point of initial dispute between the developer and the local authority was over the adoption of roads, and this was quickly resolved.

In the Nether Edge development, the boundary wall already existed as an integral part of the site. The decision by the developers to have gated access and private roads was never seen as part of the planning application, as these interview excerpts show:

«We approached the planners and they weren't taken aback, it was just something they weren't really prepared for» (Developer).

«The proposal by Gleesons was not seen as a gated community at the time. The boundary wall is part of the character of the site, and the proposal was looked at as a whole» (P1).

The way in which the Nether Edge gated community went through the planning process has certain similarities with previous studies. CASTEll (1997) examined the Bow Quarter, a gated community developed from a former factory, also a listed building, in Tower Hamlets, London. There was only one representation made in response to the planning application from residents outside the development, and this was on the grounds of inadequate parking. CASTELL concludes that: «it is hard to imagine that Bow Quarter would have turned out differently had the local planning authority not been involved in the development process. It is clear that this development took place in an environment where the market reigns» (CASTELL 1997: 54).

The Tower Hamlets planners approached the planning process as if the Bow Quarter were a regular luxury housing scheme, and the potential social and environmental implications of it as a gated community were not considered. The developers paid $£ 250,000$ under a section 106 agreement, and the planners were very satisfied with how the development worked out (CASTELL 1997: 87-88).

GooBLAR's study (2002) contrasts two planning applications for gated communities in two London boroughs. The first case involved an application to gate off an Edwardian street in a wealthy area of the Royal Borough of Kensington and Chelsea. Neighbouring residents organised a very effective opposition, and the application was turned down both by the local authority and on appeal to the Planning Inspector. The reasons for rejection were that the application did not conform to the Development Plan. However, it seems that gating off an area previously accessible to the public is intrinsically more problematic than the conversion of a site to which the public has not previously had unrestricted access. GooblaR's second case is remarkably similar to Nether Edge. A developer obtained planning permission to convert a former college campus, already walled, into a gated community in the borough of Southwark. However, the restriction of public access was not mentioned in the original planning application, merely appearing in a sketch submitted much later. There were no objections from local residents, and the developer paid $£ 250,000$ towards Southwark's affordable housing fund.

McKenzIE examines the reasons for the spread of gated communities in the US and concludes that:

«The role of government has been largely permissive and promotional rather than regulatory or directive. (...) At the same time, the (real estate) industry worked hard to create and sustain a market for that product» (McKenZIE 1994: 105).

While English urban policy is clear on the benefits of mixed neighbourhoods, government guidance is confused on the details of how these can be created. There is no guidance at all on how local authorities should treat planning applications to develop single-class, single-tenure gated communities.

The second half of McKenzIE's conclusion, on marketing efforts by developers, probably holds true in England. Certainly in Sheffield, local authority officers felt that:

«Gleesons now seem to be marketing the site as something which Planning didn’t envisage» (P1).

«A lot of it [keeping the development gated and private] seemed to be marketing, to be honest» $(\mathrm{H} 2)$.

We now turn to examine how the Nether Edge gated community was marketed, and the motivation of the people who purchased properties there. 


\section{Supply and demand in Nether Edge}

The marketing material for the Nether Edge gated community, in line with globalised trends, emphasises that the development is designed for a «Life of leisure, life of security, life of luxury, featuring hi-tech, loft style apartments». The sales negotiators have been specially trained to conduct potential purchasers on a guided tour of the show house, pointing out the hi-tech and convenience features. However, in interview the developer expressed his personal view that

«from a marketing point of view, it's definitely the security (...) peace of mind. What do we need to make ourselves distinctly different? Answer: if it's enclosed, make it secure.»

As the surrounding wall already existed, «adding gates and security wasn't a big deal».

Analysis of the residents' questionnaires reveals that their reasons for moving to the development, in order of importance, are: firstly, the security features; then, maintenance of property values; followed by proximity to job, equally important as the leisure facilities; and lastly, moving into a community. None of the interviewees felt that the area was particularly dangerous or prone to crime, but security for their cars and children were the main reasons they gave for choosing to live behind the gates. The residents appreciated the convenience and hi-tech features of a new conversion combined with the architectural features of an historic building. Most interviews included comments such as:

«We wanted an older house, but having run (one before) we didn't want the cost that incurs with that and the maintenance of things.»

«The house itself I absolutely love, the way that it's been planned, the architecture of it, the fact that it is old but with all of the modern features as well.»

The architecturally sensitive conversion, attention to detail, and the marketing of Nether Edge as a secure, luxury development, have clearly paid off for both developer and residents. House prices are around 15\% higher than equivalent property in the surrounding area, which is already well above the national average. The case study bears out the hypotheses that consumer demand is driven by globalised marketing trends and fear of crime, all of which are alluded to in the developer's publicity material. The most recent sales advertisement reads:

«Set in 10 acres of private grounds, with $24 \mathrm{hr}$ CCTV security gate system and exclusive residents' leisure facilities, this is living as you've never known it before» (SHEFFIELD NewSPAPERS Limited 2003).

In fact, as can be seen from Figure 2, the 10 acres are very densely developed, with a large proportion of the «grounds» given over to car parking space.

\section{Conclusions}

There is an increasing realisation that social and community aspects of housing provision are at least as important for the satisfaction of residents as the physical fabric. The broad intention of English urban policy can be seen as reducing social division by creating a more balanced society, and reducing social exclusion through mixed communities and mixed tenure. However, the structural forces at work in society in general and the housing markets in particular seem to be running contrary to these intentions.

This article has suggested that globalised market trends in housing may lead to the development of more gated communities in the UK, reflecting the experience of the USA and other countries as diverse as China, Brazil and Ireland. Our concern is that the development of gated communities will reflect and reinforce the social divisions which are occurring as a result of structural, social and economic forces in the housing market. Gated communities are contrary to the main thrust of policy in that they are usually single class, single income, single tenure estates, rather than the mixed balanced communities envisaged in a range of policy documents.

The case studies suggest that the planning system does not control the development of gated communities to achieve policy aims of this type. However, signs are emerging that the attitude of some local planning authorities may be changing. At least two London boroughs, Southwark and Lambeth, have recently been reported as including a principled objection to gated communities in their Development Plans. Southwark's Plan states:

«We will seek to try to resist gated developments because of their exclusive nature and because they discourage the free-flow of pedestrians» (LoNSDALE 2003).

However, so far, these are isolated examples.

We suggest that there is a need for a clear and consistent approach by all planning authorities to the issue of gated communities, following clear national policy. Further unregulated increase of such developments may lead to:

- a majority of newbuild housing being gated, driven by globalised attitudes and marketing strategies;

- increased social division and discrepancy between the «haves» and the «have nots»;

- reinforcement of the fear of crime;

- the privatisation of urban space and governmental function;

- encouragement of small inward-looking communities with privileged provision.

For these reasons a public debate is needed to develop 
a coherent approach to gated communities through the planning system.

\section{References}

ACPO Crime Prevention Initiatives Ltd (2003): Secured by Design. - http://www.securedbydesign.com 20.02.2003.

BECK, U. (2000): What is Globalisation? - Cambridge: Polity Press.

Burrows, R. \& D. Rhodes (2001): Unpopular places? Area disadvantage and the geography of misery in England. - York: The Policy Press in association with the Joseph Rowntree Foundation.

CASTELL, B. (1997): An Investigation into Inward-Looking Residential Developments in London. - London: University College, unpublished M. Phil. Thesis, University College, London University.

Department of the EnVIRONMENT, TRANSPORT AND ThE Regions (DETR) (2000a): Our Towns and Cities: The Future - Delivering an Urban Renaissance (The Urban White Paper). - London: Office of the Deputy Prime Minister (ODPM).

Department of the Environment, Transport and the Regions (DETR) (2000b): National Strategy for Neighbourhood Renewal. - London: Office of the Deputy Prime Minister (ODPM).

Department of The Environment, Transport and the Regions (DETR) (2000c): Planning Policy Guidance Note 3: Housing. - London: Office of the Deputy Prime Minister (ODPM).

Department of the Environment, Transport and the Regions (DETR)/Department of Social SecuRITY (DSS) (2000): Quality and choice: A decent home for all (The Housing Green Paper). - London: Department of the Environment, Transport and the Regions.

Department of TRANSPort, Local Government and the Regions (DTLR) (2001): Better Places to Live by Design: a companion guide to PPG3. - London: Office of the Deputy Prime Minister (ODPM).

Garber, M. (2000): Sex and Real Estate: Why We Love Houses. - New York: Anchor.

GARLAND, D. (2001): The Culture of Control: Crime and Social Order in Contemporary Society. - Oxford: Oxford University Press.

Gooblar, A. (2002): Outside the Walls: Urban Gated Communities and their Regulation within the British Planning System. - In: European Planning Studies 10, 3: 321-334.

Halifax New Homes Marketing Board (2001): New Homes Today. - Halifax: Halifax plc.

Home Office (2002): British Crime Survey 2001. London: The Home Office.

Live Strategy (2002): Telephone Survey into attitudes towards gated communities in England. - London: Royal Institute of Chartered Surveyors (RICS).
LONSDALE, S. (2003): Through the barricades. - In: The Sunday Telegraph, 2.03.2003, London: Review page 17.

McKenzie, E. (1994): Privatopia: Homeowner Associations and the Rise of Residential Private Government. - New Haven: Yale University Press.

Morley, D. (2001): Belonging - place, space and identity in a mediated world. - In: European Journal of Cultural Studies 4.

Page, D. (1993): Building for Communities. - York: Joseph Rowntree Trust.

Putnam, R.D. (2000): Bowling Alone: the collapse and revival of American community. - New York: Simon and Schuster.

Robinson, P.S. (2002): Local Expressions of Globalising Capitalist Society: The Privatisation and Fortification of Public Space. - Paper presented to the Private Urban Governance Conference, Johannes GutenbergUniversity, Mainz, 5-8 June 2002.

Sheffield City Council (1997): Planning Brief for Nether Edge Hospital. - Sheffield: Directorate of Planning and Economic Development.

Sheffield City Council (2001): Review of the Unitary Development Plan, Full Listing of Issues. - Sheffield: Directorate of Planning and Economic Development.

Sheffield Newspapers Limited (2003): Sheffield Property Guide March 21 2003. - Sheffield: Sheffield Newspapers Limited.

THORns, D.C. (2001): The Making of Home in a Global World. - Paper presented to the Managing Housing and Social Change conference, City University of Hong Kong, 16-18 April 2001.

URbAN TASK Force (1999): Towards an Urban Renaissance. - London: Office of the Deputy Prime Minister (ODPM).

Webster, C. (2001): Gated Cities of Tomorrow. - In: Town Planning Review 72, 2: 149-170.

\section{Summary: Gated Communities in England: rules and rhetoric of urban planning}

The number of private gated developments continues to grow in Britain, in apparent contradiction to the government's urban policy aims of developing balanced, sustainable, mixed communities. There has been no official recognition of the trend towards gated communities, nor any national debate about their desirability as a built or social form. Contradictory guidance is given to local authorities about the design priorities for new housing developments. A case study tracks the planning process of a gated community in Sheffield in order to illustrate the problems of regulating this new form of housing. Interviews with key players in this development inform discussion about the supply and demand for gated communities, which are found to be influenced by globalised marketing trends for 
ideal housing types, and a pervasive fear of crime. The issues which are highlighted by the growth of gated communities in Britain demand more attention than can be provided by the current policy vacuum.

\section{Zusammenfassung: Gated Communities in England - Regeln und Rhetorik der Stadtplanung}

Die Zahl privater, geschlossener Wohnprojekte in Großbritannien wächst kontinuierlich an. Dieser Prozess steht in offensichtlichem Widerspruch zur Stadtentwicklungspolitik der Regierung, die auf die Entwicklung sozial ausgewogener, nachhaltiger und gemischter Nachbarschaften zielt. Der Trend zu gated communities ist bislang nicht offiziell anerkannt, eine öffentliche Auseinandersetzung darüber, ob diese Wohnform als städtebauliche und soziale Konfiguration erstrebenswert ist, findet nicht statt. Den lokalen Behörden werden widersprüchliche Anleitungen zu den städtebaulichen Leitlinien für neue Wohnprojekte gegeben. Eine Fallstudie verfolgt die Entwicklung einer gated community im öffentlichen Planungsprozess in Sheffield und illustriert damit die Probleme bei der öffentlichen Steuerung dieser Wohnform. Interviews mit Schlüsselpersonen dieses Projektes geben Hinweise für die Diskussion über das Angebot von und die Nachfrage nach gated communities. Es zeigt sich, dass Angebot und Nachfrage von globalisierten Marketing-Trends für eine ideale Art des Wohnens sowie umfassenden Kriminalitätsängsten beeinflusst werden. Die Probleme, die das Wachstum der gated communities in Großbritannien aufzeigen, verlangen mehr Aufmerksamkeit, als das derzeitige PolitikVakuum aufbringen kann.

\section{Résumé: Les gated communities en Angleterre - les règles et la rhétorique de l'aménagement urbain} Le nombre de projets d'habitations privées sécurisées en Grande Bretagne ne cesse d'augmenter. Ce processus est en apparente contradiction avec la politique urbaine du gouvernement qui consiste à développer des communautés d'habitation durables, mixtes et socialement équilibrées. Cette tendance à la création de gated communities n'est pas officiellement reconnue. L'opportunité d'une telle forme de construction urbaine et sociale n'a fait l'objet d'aucun débat national. Les directives qui sont données aux autorités locales quant à l'aspect des nouveaux projets immobiliers sont antithétiques. A Sheffield, le processus de planification urbaine représente un cas d'étude qui suit le développement d'une gated community et illustre les problèmes de contrôle des formes d'habitations. L'interview de personnes jouant un rôle clé dans le développement de projets de ce type a nourri la discussion relative à l'offre et la demande en matière de telles gated communities. Il a été observé que l'offre et la demande étaient influencées par la tendance globale du marché à rechercher un modèle de maison idéale, ainsi que par le sentiment de peur face à la criminalité. Les problèmes qui sont soulignés par l'accroissement du nombre de gated communities en Grande-Bretagne requièrent plus d'attention que celle susceptible d'être générée par le vide politique actuel.

\section{Teaching of Geography - relevant questions}

- List the reasons the authors give to explain the boom of gated communities in Great Britain.

- How does globalisation affect and alter traditional images of the «ideal home»?

- What fears and aspirations are used by developers to encourage demand for gated communities?

- Why don't local planning authorities enforce the government's policies to encourage inclusive and mixed neighbourhoods?

- What are the goals of the national urban development policy?

- List the reasons given by buyers for purchasing property in gated communities.

Sarah Blandy, Senior Lecturer in Housing Law, and David Parsons, Senior Lecturer in Planning and Development: School of Environment and Development, Sheffield Hallam University, Howard Street, Sheffield S1 1WB, United Kingdom.

e-mail:

s.blandy@shu.ac.uk

d.e.parsons@shu.ac.uk

\section{Manuskripteingang/received/manuscrit entré le} 24.8.2003

Annahme zum Druck/accepted for publication/accepté pour l'impression: 8.12.2003 